\title{
Review: David Martin Jones, Cinema Against Doublethink: Ethical Encounters with the Lost Pasts of World History
}

Sanghita Sen

DOI: 10.15664/fcj.v0i18.2271

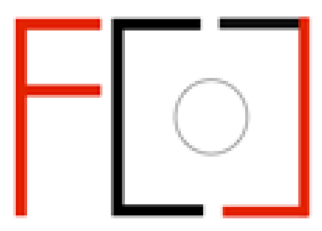

Frames Cinema Journal ISSN 2053-8812

Issue 18 (Jun 2021)

http://www.framescinemajournal.com

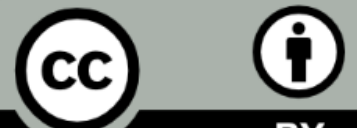




\section{Cinema Against Doublethink: Ethical Encounters with the Lost Pasts of World History By David Martin-Jones}

Routledge, 2018

Review by Sanghita Sen, University of St Andrews

The interdisciplinary investigation of Cinema Against Doublethink: Ethical Encounters with the Lost Pasts of World History follows "a plurality of approaches from a world of philosophies" (49). The book engages with insights ranging from the world systems theory of Immanuel Wallerstein furthered by Enrique Dussel in his idea of "colonial modernity and ethics of liberation"; to Anibal Quijano's concept of "coloniality of power" and dependence theory (i.e. in the premises of Western modern/colonial imperialisms, modernity and coloniality are interdependent) fostered by Walter Mignolo in his ideas of decolonisation and decoloniality; to the idea of unthinking Eurocentrism as proposed by Ella Shohat and Robert Stam. However, the two principal theoretical frameworks that this book depends on to formulate its critique of Eurocentrism and champion cinema's redemptive potential, are Dussel's idea of world history and Gilles Deleuze's idea of time-image. Using their insights as tools for critical intervention, the author engages with the history of transnational cinema, including Third Cinema, and its legacy of decolonising creative practices in the Global South. To enable a better understanding of "how the stories of world history are told across borders" through cinema (40), David Martin-Jones proposes the destabilisation of Eurocentric discourses on cinema that situates the idea of the nation as central to it, as an extension of Western imperialist epistemology. Instead, the book foregrounds the intertwined nature of transnational history and collective responses to colonial modernity as a continuum of centuries-old colonialism to more recent neoliberal globalisation. Initiating a conversation and critical engagement with these concepts is one of the most important contributions of the book.

Starting with the preface itself, the author, contextualises his argument using narrative tools and metaphors to explain the relationship between truth and historiography and how 
staging of "doublethink" is executed in it, placing the need for decolonising the historical discourse at the centre of his book. Across the eight chapters (including the introduction and conclusion), Martin-Jones critically engages with the idea of doublethink, the need to "unthink" it, and the strategic use of "alternative facts" to unmask the official history in circulation. The impressive corpus of fiction and nonfiction films that the author critically engages with is thematically, culturally, and geographically extensive and diverse and includes the films Loong Boonmee raleuk chat/Uncle Boonmee Who Can Recall His Past Lives (Dir. Apichatpong Weerasethakul, Thailand/UK/France/Germany/Spain/Netherlands, 2010), Nostalgia de la luz/Nostalgia for the Light (Dir. Patricio Guzmán, Chile/Spain/France/Germany/USA, 2010), Como era gostoso o meu francês/How Tasty Was My Little Frenchman (Dir. Nelson Pereira dos Santos, Brazil, 1971), También la Lluvia/Even the Rain (Dir. Icíar Bollaín, Spain/Mexico/France, 2010), The Act of Killing (Dir. Joshua Oppenheimer, Denmark/Norway/UK, 2012), Al pie del árbol blanco/At the Foot of the White Tree (Dir. Juan Alvarez Neme, Uruguay, 2007), Carancho/Vulture (Dir. Pablo Trapero, Argentina/Chile/France/South Korea, 2010), Chinjeolhan geumjassi/Lady Vengeance (Dir. Chanwook Park, South Korea, 2005) etc.. However, I was slightly disappointed with the absence of cinema from the Indian subcontinent, one of the most influential film cultures of the Global South which also has a robust oppositional cinema.

What I particularly found fascinating about the book is its keen attention to the recovery of many pasts and many voices challenging the monolithic official history - of "the linear, developmental model of colonial modernity" (19)—which presents itself as a singular narrative with an air of authority and absoluteness. Alongside critiquing Western historical narratives, Martin-Jones also problematises prevalent practices of viewing and curation of cinema (across the world) based on a Eurocentric historiographic ideals. He does that to accentuate the importance of changing our methodologies to complement sincere engagement with many 
pasts and successfully challenge doublethink propagated by the official history. The book kept me glued for its commitments to the silent/silenced part of history and emphasis on including multiple voices as legitimate sources of history beyond the Anthropocene.

Cinema Against Doublethink caught my immediate attention as a researcher from the Global South-working on transnational political cinema with deep investment in decolonisation - who was made to re-learn her history written by the victor that did not accord with her lived experiences, and was subjected to constant suspicion about her understanding of history which was often dismissed for being "anecdotal" within academia. Consequently, my engagement with this book turned out to be simultaneously academic and profoundly personal, both because of its political and cultural relevance in our time as well as the nuanced utilisation of the Orwellian concept of "doublethink" with reference to the writing of history and the author's deliberation about cinema with a capacity to "reclaim the truth of history" subverting the "doublethink" in the era of post-truth, an idea that gained traction in context of the Brexit vote and the 2016 American presidential elections. Despite the fine differences between the ideas of "doublethink" and post-truth, both share a common conceptual premise of negating important facts and information to manipulate history and people's minds towards achieving dogmatic goals or to sanitise the Western historical narratives under colonial modernity. The question is then how is the "alternative" version of silenced/negated history different from the Orwellian "doublethink" or the "post-truth" particularly in context of a time when the term "alternative" has gained such negative connotation through its association with fake news used as a "political strategy" by the reactionary forces not only to create "cognitive dissonance" but also to "foster disengagement with the political process" among the masses (7)? The crucial difference, as Martin-Jones identifies, is that of political intent and ethics with which the critical theory has been using the term "alternative" to "debunk, deconstruct, unmask" hitherto overlooked views of reality and to recover the "lost past" (5-7). The present time is the most 
urgent time for reclaiming the term "alternative" in a world captivated by right-wing propaganda. The pauses between reading parts of the book and reflecting on arguments made therein were very satisfying. The lucid language with which the book presents - highly complex ideas, made me feel as if I was participating in a prolonged seminar, in conversation with its author, and the many scholars that he cites. Given the recent resurgence of interest in Third Cinema, Cinema Against Doublethink is a crucial contribution to the scholarship of political cinema that is grounded in case studies, posits innovative insights into film methodology. 